\title{
Infographic. ISPAH's Eight Investments That Work for Physical Activity: infographic, animation and call to action
}

The International Society for Physical Activity and Health

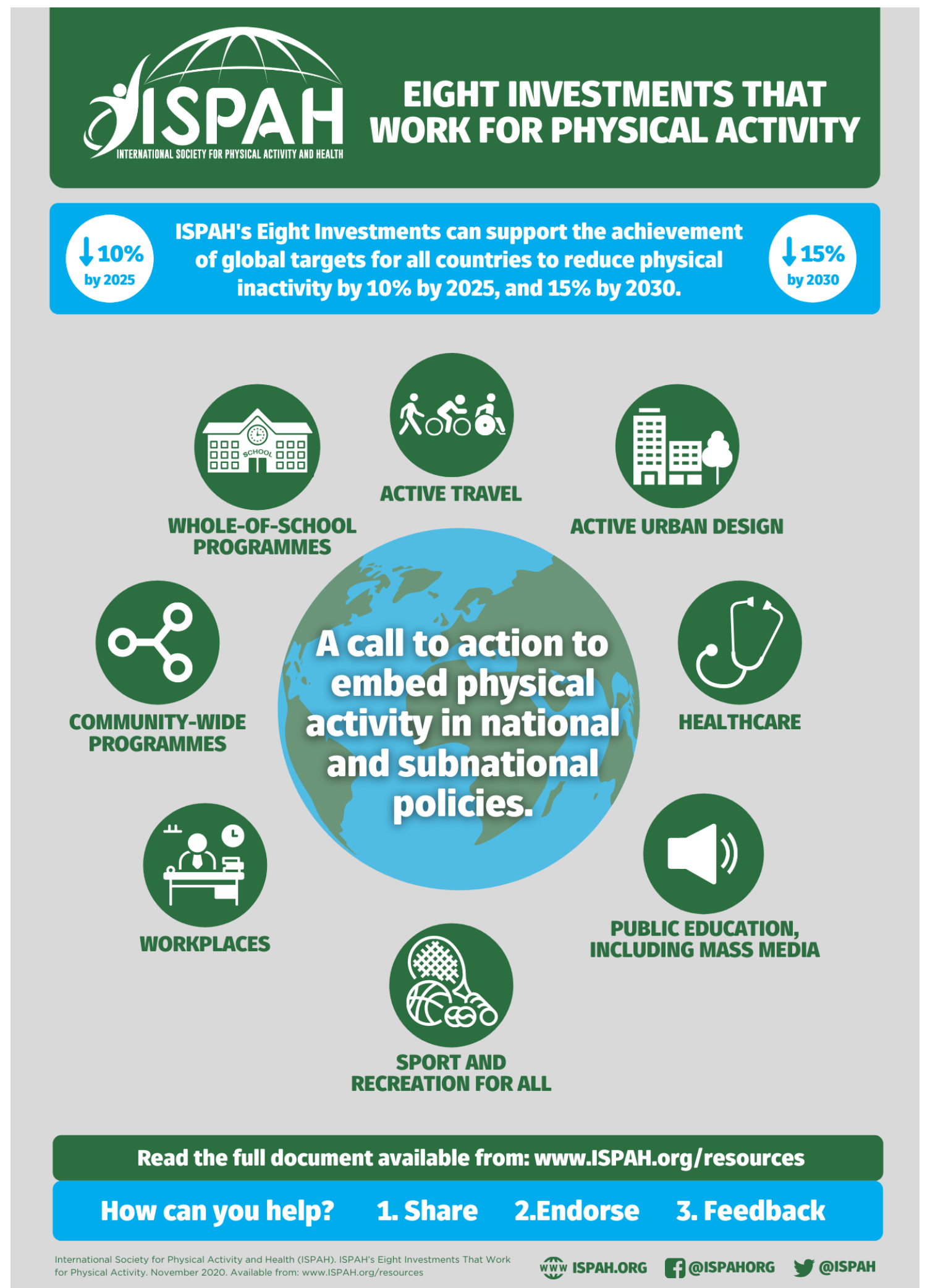

Figure 1 Infographic. 
Physical activity is an encompassing term for all human movement, in homes, schools, organisations and communities. Physical activity benefits individuals and societies, contributing to many of the United Nations Sustainable Development Goals, as outlined in International Society for Physical Activity and Health (ISPAH)'s Bangkok Declaration. ${ }^{1}$ The health benefits of physical activity are established and multifaceted and include reduced risk of a wide range of non-communicable diseases as well as improved mental health, sleep and cognitive function. ${ }^{2}$

Globally, around one in four adults and four in five adolescents are insufficiently active, ${ }^{34}$ and inequities in participation exist by geography, sex and socioeconomic status. In response, two targets have been endorsed by the World Health Assembly, for a global reduction in physical inactivity by $10 \%$ by 2025 and $15 \%$ by $2030 .^{5}$ In order to achieve these targets, advocacy and delivery efforts will need to be accelerated. ${ }^{34}$ A key tenet of successful public health advocacy is gaining consensus on 'what works'. ISPAH's Eight Investments That Work for Physical Activity ${ }^{6}$ provides eight areas for action, supporting the WHO Global Action Plan on Physical Activity 2018-2030. ${ }^{5}$

\section{WHAT ARE THE EIGHT INVESTMENTS THAT WORK?}

ISPAH's Eight Investments That Work for Physical Activity ${ }^{6}$ provides a summary of eight areas for action that are supported by scientific evidence and have worldwide applicability. It is a 'call to action for everyone, everywhere, including professionals, academics, civil society and decision makers, to embed physical activity in national and subnational policies'. The document updates and builds upon the 2010 Toronto Charter for Physical Activity $^{7}$ and accompanying 2011 Investments that Work for Physical Activity. ${ }^{8}$

Central to ISPAH's Eight Investments That Work for Physical Activity ${ }^{6}$ is a system-based approach. Recognising there is no single solution to increase physical activity, this document acknowledges that investments should not be expected to work in isolation; instead they should be combined to work together in a coherent and complementary way. It recognises that multiple stakeholders from diverse contexts can, and should, be united to tackle physical inactivity. Some stakeholders will be new to our physical activity agenda. By engaging in a systembased approach, these stakeholders can not only connect how their work contributes to physical activity promotion but also how their agenda is influenced by promoting physical activity. As an example, transport planners who want to build a bicycle network will understand that cycle paths are a highly efficient use of space for transport, but through a systembased approach, they will also recognise the co-benefits to local businesses and population levels of physical activity.

ISPAH has adapted the content of ISPAH's Eight Investments That Work for Physical Activity ${ }^{6}$ into an infographic (figure 1) and an animation (https://youtu. be/CMjizuPU9tQ) to increase awareness of the initiative, distill key information for a wide range of stakeholders and re-emphasise the 'call to action'. Our ambition is that this document will be used by physical activity advocates around the world to make the case for investment and action as well as to mobilise communities globally to create a more physically active world. Readers can find further advocacy tools on the ISPAH website in the advocacy toolkit: www.ispah.org/resources.

Correspondence to The International Society for Physical Activity and Health, Prevention Research Collaboration, Charles Perkins Centre, The University of Sydney, Sydney, New South Wales, Australia; info@ispah.org

Correction notice This article has been corrected since it published Online First. The correspondence details have been updated andthe provenance and peer review statement has been included.

Acknowledgements The International Society for Physical Activity and Health (ISPAH) Board of Governors would like to thank the Working Group which developed the full document 'ISPAH's Eight Investments That Work for Physical Activity': Trevor Shilton, Matthew Mclaughlin, Lindsey Reece, Charlie Foster, Karen Milton, Anna Chalkley, Sjaan Gomersall, Jasper Schipperijn, Maria Hagströmer, Ben Smith, Paul Kelly, Tracy KolbeAlexander, Jacqueline Mair, James Nobles and Nick Cavill. Additionally, we would like to thank Simone Tomaz and the Society's Communications Committee for their contribution to the dissemination plan.

Collaborators ISPAH International Society for Physical Activity and Health.

Contributors Matthew Mclaughlin developed the infographic, animation and the draft of this manuscript. MM led the revisions of the infographic, animation and manuscript. Trevor Shilton, Lindsey Reece, Simone Tomaz, Jacqueline Mair, Karen Milton, Charlie Foster, Tracy Kolbe-Alexander, Sjaan Gomersall, Maria Hagströmer, Jasper Schipperijn, Catherine Draper, James Nobles, Nick Cavill, Anna Chalkley and Paul Kelly provided feedback on multiple drafts of the infographic, animation and manuscript.
Funding The authors have not declared a specific grant for this research from any funding agency in the public, commercial or not-for-profit sectors.

Competing interests None declared.

Patient consent for publication Not required.

Provenance and peer review Not commissioned; internally peer reviewed.

\section{(0) OPEN ACCESS}

Open access This is an open access article distributed in accordance with the Creative Commons Attribution Non Commercial (CC BY-NC 4.0) license, which permits others to distribute, remix, adapt, build upon this work non-commercially, and license their derivative works on different terms, provided the original work is properly cited, appropriate credit is given, any changes made indicated, and the use is non-commercial. See: http://creativecommons.org/ licenses/by-nc/4.0/.

(C) Author(s) (or their employer(s)) 2021. Re-use permitted under CC BY-NC. No commercial re-use. See rights and permissions. Published by BMJ.

\section{Check for updates}

To cite . Br J Sports Med 2021;55:759-760.

Accepted 12 December 2020

Published Online First 13 January 2021

Br J Sports Med 2021;55:759-760.

doi:10.1136/bjsports-2020-103635

\section{REFERENCES}

1 ISPAH International Society for Physical Activity and Health. The Bangkok Declaration on physical activity for global health and sustainable development. Br I Sports Med 2017;51:1389-91.

22018 Physical Activity Guidelines Advisory Committee. 2018 physical activity guidelines Advisory Committee scientific report. U.S. Department of Health and Human Services, 2018

3 Guthold R, Stevens GA, Riley LM, et al. Global trends in insufficient physical activity among adolescents: a pooled analysis of 298 population-based surveys with 1.6 million participants. Lancet Child Adolesc Health 2020;4:23-35

4 Guthold R, Stevens GA, Riley LM, et al. Worldwide trends in insufficient physical activity from 2001 to 2016: a pooled analysis of 358 population-based surveys with 1.9 million participants. Lancet Glob Health 2018:6:e1077-86.

5 World Health Organization. Global action plan on physical activity 2018-2030: more active people for a healthier world. Geneva: World Health Organization, 2018.

6 International Society for Physical Activity and Health (ISPAH). ISPAH's Eight Investments That Work for Physical Activity, 2020. Available: www.ispah.org/ resources

7 The International Society for Physical Activity and Health (ISPAH). The Toronto charter for physical activity: a global call for action, 2010.

8 The International Society for Physical Activity and Health (ISPAH). Investments that work for physical activity, 2011. 